\title{
\#USGS
}

One-Meter Topobathymetric Digital Elevation Model for Majuro Atoll, Republic of the Marshall Islands, 1944 to 2016

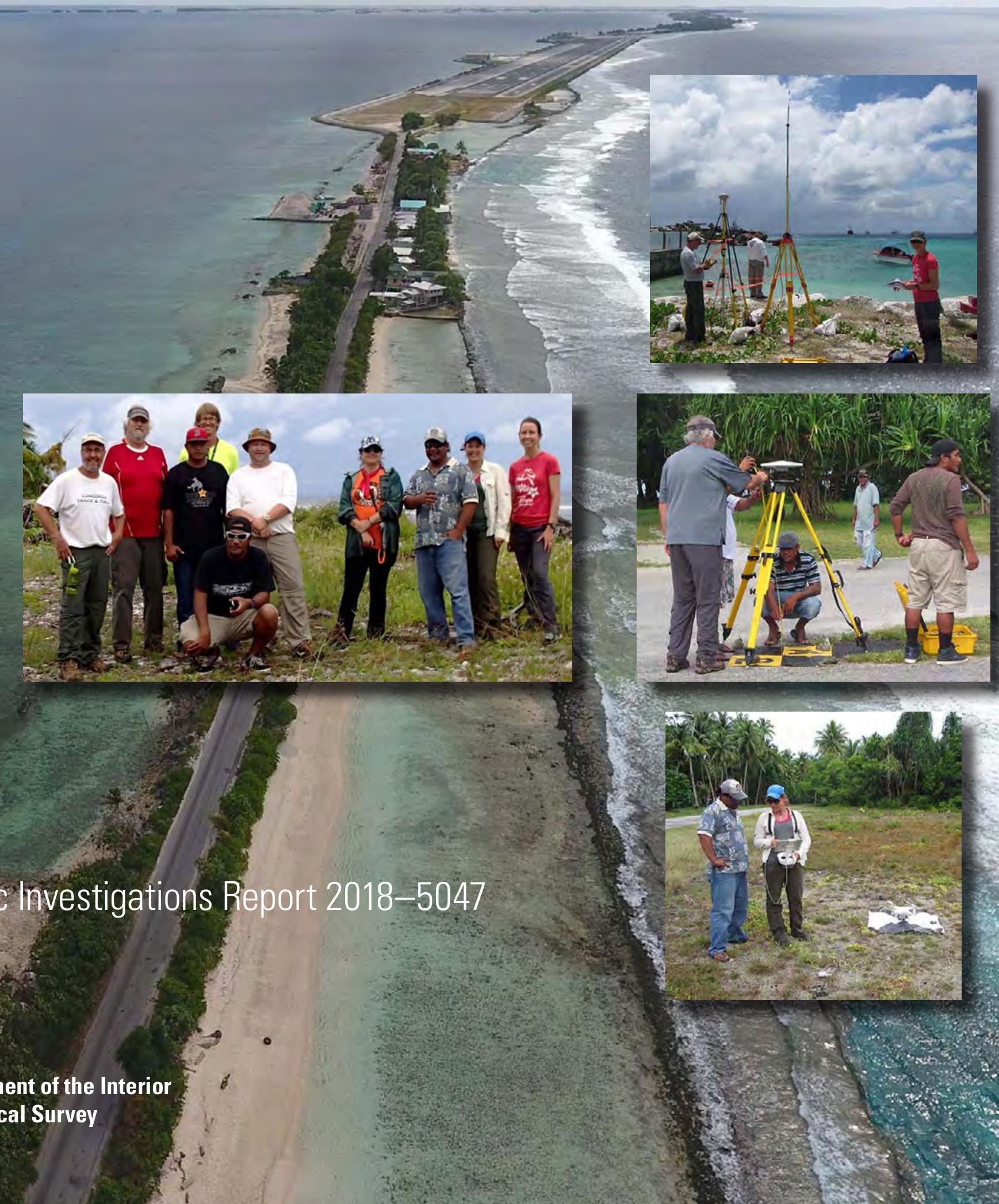


Cover. Aerial view (looking southeast) of the southern part of the Majuro Atoll, Republic of the Marshall Islands, September 2016. Majuro International Airport is in the background.

Inset photographs. Several authors of the report and survey crew team members at various field sites on the atoll during data collection, September 2016. Middle center photograph, from left to right: Dean Gesch (USGS), Edward Carlson (NOAA), Makzine Lakjohn (RMI Office of Lands and Survey), Fritzad Reiher (RMI Office of Lands and Survey), Matthew Barbee (University of Hawaii), Jeffrey Danielson (USGS), Monica Palaseanu-Lovejoy (USGS), Bill Labija (RMI Office of Lands and Survey), Maria Kottermair (University of Guam), and Cindy Thatcher (USGS). 


\section{One-Meter Topobathymetric Digital Elevation Model for Majuro Atoll, Republic of the Marshall Islands, 1944 to 2016}

By Monica Palaseanu-Lovejoy, Sandra K. Poppenga, Jeffrey J. Danielson, Dean J. Tyler, Dean B. Gesch, Maria Kottermair, Andrea Jalandoni, Edward Carlson, Cindy A. Thatcher, and Matthew M. Barbee

Scientific Investigations Report 2018-5047 


\title{
U.S. Department of the Interior \\ RYAN K. ZINKE, Secretary
}

\section{U.S. Geological Survey William H. Werkheiser, Deputy Director exercising the authority of the Director}

\author{
U.S. Geological Survey, Reston, Virginia: 2018
}

For more information on the USGS - the Federal source for science about the Earth, its natural and living resources, natural hazards, and the environment-visit https://www.usgs.gov or call 1-888-ASK-USGS.

For an overview of USGS information products, including maps, imagery, and publications, visit https://store.usgs.gov.

Any use of trade, firm, or product names is for descriptive purposes only and does not imply endorsement by the U.S. Government.

Although this information product, for the most part, is in the public domain, it also may contain copyrighted materials as noted in the text. Permission to reproduce copyrighted items must be secured from the copyright owner.

Suggested citation:

Palaseanu-Lovejoy, M., Poppenga, S.K., Danielson, J.J., Tyler, D.J., Gesch, D.B., Kottermair, M., Jalandoni, A., Carlson, E., Thatcher, C.A., and Barbee, M.M., 2018, One-meter topobathymetric digital elevation model for Majuro Atoll, Republic of the Marshall Islands, 1944 to 2016: U.S. Geological Survey Scientific Investigations Report 2018-5047, 16 p., https://doi.org/10.3133/sir20185047.

ISSN 2328-0328 (online) 


\section{Contents}

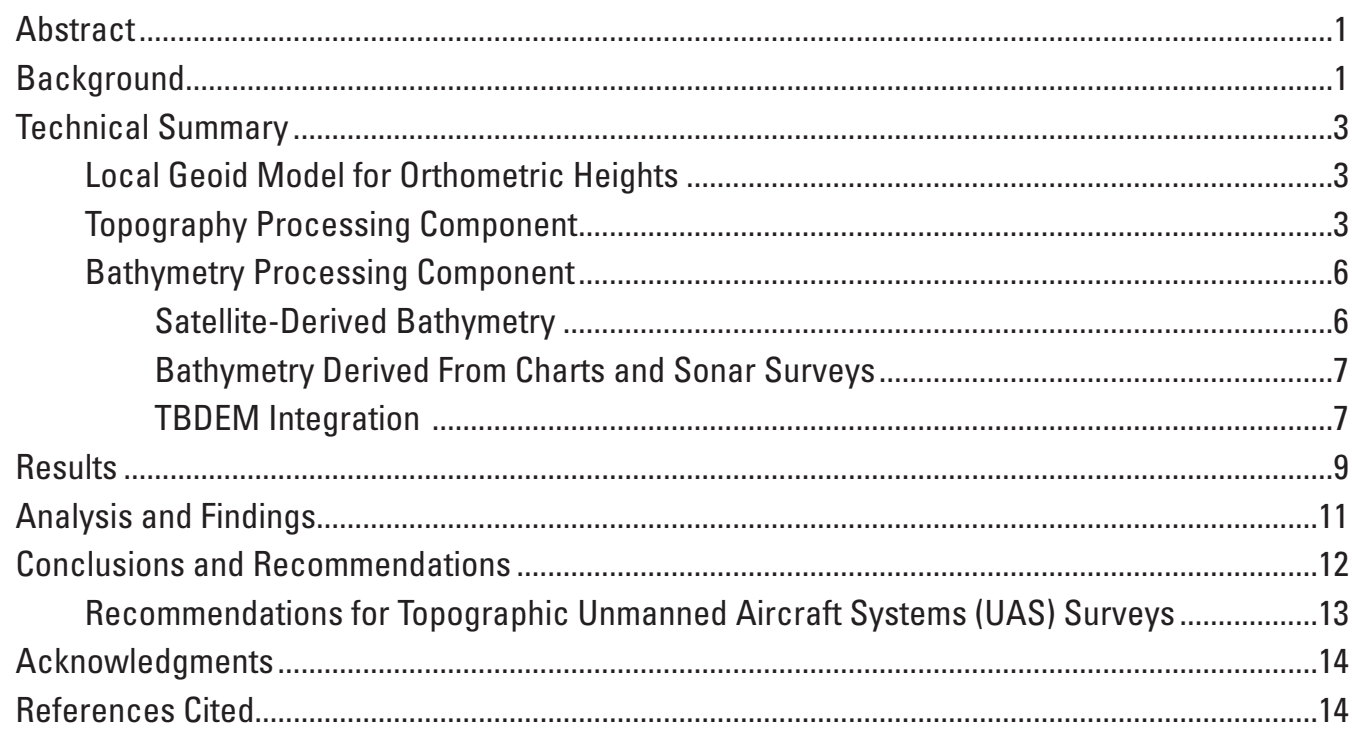

\section{Figures}

1. Map showing the location of Majuro Atoll, Republic of the Marshall Islands

2. Photographs showing Global Navigation Satellite System real-time kinematic survey points collected on Majuro Atoll, Republic of the Marshall Islands, during field work from September 14 to September 26, 2016

3. Diagram showing the typical workflow to derive georeferenced dense 3D point clouds using structure-from-motion algorithms implemented in Agisoft PhotoScan.......5

4. Diagram illustrating the Multiscale Model-to-Model Cloud Comparison principle ..........6

5. Map of the Majuro Atoll topobathymetric digital elevation model (TBDEM) spatial metadata showing the location and areal extent of data used to generate the integrated TBDEM

6. Map showing the Majuro Atoll topobathymetric digital elevation model at 1-meter resolution 


\section{Tables}

1. Error metrics using ground control points. .9

2. Validation measurements results using Global Navigation Satellite System points.........9

3. Validation measurements results for satellite-derived bathymetry using Compact Hydrographic Airborne Rapid Total Survey lidar data.

4. Error metrics for the three different satellite-derived bathymetry areas segmented by water depth

5. Limits for accuracy and vertical root mean square error of the Pacific Islands Applied Geoscience Commission data using International Hydrographic Organization (2008) standards

\section{Conversion Factors}

International System of Units to U.S. customary units

\begin{tabular}{lcl}
\hline \multicolumn{1}{c}{ Multiply } & By & \multicolumn{1}{c}{ To obtain } \\
\hline & Length & \\
\hline centimeter $(\mathrm{cm})$ & 0.3937 & inch (in.) \\
meter $(\mathrm{m})$ & $39.37 / 12$ & U.S. Survey foot $(\mathrm{ft})$ \\
meter $(\mathrm{m})$ & $1 / 0.3048$ & International foot $(\mathrm{ft})$ \\
meter $(\mathrm{m})$ & 1.094 & yard $(\mathrm{yd})$ \\
\hline & Area & \\
\hline square meter $\left(\mathrm{m}^{2}\right)$ & 0.0002471 & acre \\
square kilometer $\left(\mathrm{km}^{2}\right)$ & 247.1 & acre \\
square meter $\left(\mathrm{m}^{2}\right)$ & 10.76 & square foot $\left(\mathrm{ft}^{2}\right)$ \\
square kilometer $\left(\mathrm{km}^{2}\right)$ & 0.3861 & square mile $\left(\mathrm{mi}^{2}\right)$ \\
\hline
\end{tabular}




\section{Supplemental Information}

Elevation, as used in this report, refers to elevation above local mean sea level (LMSL), unless specifically referenced to the ellipsoid.

\section{Abbreviations}

2D

two dimensional

$3 \mathrm{D}$

three dimensional

ACOMP

DigitalGlobe Atmospheric Compensation

ASTER

Advanced Spaceborne Thermal Emission and Reflection Radiometer

CHARTS

Compact Hydrographic Airborne Rapid Total Survey

$\mathrm{cm}$

centimeters

CMGP

Coastal and Marine Geology Program

CMVS

clustering views for multi-view stereo

CoNED

Coastal National Elevation Database

DEM

digital elevation model

DOI

U.S. Department of Interior

$\mathrm{E}$

east, or easting

ENVI

Environment for Visualizing Images

Esri

Environmental Systems Research Institute

GDEM V2

Global Digital Elevation Model Version 2

GNSS

Global Navigation Satellite System

GSP

ground control points

IGN

National Institute of Geographic and Forest Information

IHO

International Hydrographic Organization

$\mathrm{km}$

kilometers

$\mathrm{km}^{2}$

square kilometers

L8

Landsat 8

lat.

latitude

LMSL

local mean sea level

long.

$\mathrm{m}$

longitude

meters

M3C2

Multiscale Model-to-Model Cloud Comparison

MAE

mean absolute error

MBES

multibeam echo sounder 


\begin{tabular}{|c|c|}
\hline ME & mean error \\
\hline MIA & Majuro International Airport \\
\hline MLWS & mean low water springs \\
\hline MSL & mean sea level \\
\hline $\mathrm{N}$ & north, or northing \\
\hline NAVOCEANO & Naval Oceanographic Office \\
\hline NGP & National Geospatial Program \\
\hline NGS & National Geodetic Survey \\
\hline NIR & near-infrared \\
\hline NOAA & National Oceanic and Atmospheric Administration \\
\hline PI-CSC & Pacific Islands Climate Science Center \\
\hline PMVS2 & patch-based multi-view stereo \\
\hline RMI & Republic of the Marshall Islands \\
\hline RMSE & root mean square error \\
\hline RTK & real-time kinematic \\
\hline SDB & satellite-derived bathymetry \\
\hline SfM & structure-from-motion \\
\hline SOPAC & Pacific Islands Applied Geoscience Commission \\
\hline SPC & Secretariat of the Pacific Community \\
\hline SRTM & Shuttle Radar Topography Mission \\
\hline SWIR-1 & shortwave infrared band 1 \\
\hline TBDEM & topobathymetric digital elevation model \\
\hline UAS & unmanned aircraft systems \\
\hline$\mu \mathrm{m}$ & microns \\
\hline USDA & United States Department of Agriculture \\
\hline USGS & United States Geological Survey \\
\hline UTM & Universal Transverse Mercator \\
\hline VIP & visually identifiable points \\
\hline W & west \\
\hline WGS 84 & World Geodetic System of 1984 \\
\hline WV-3 & WorldView-3 \\
\hline
\end{tabular}




\title{
One-Meter Topobathymetric Digital Elevation Model for Majuro Atoll, Republic of the Marshall Islands, 1944 to 2016
}

\author{
By Monica Palaseanu-Lovejoy, ${ }^{1}$ Sandra K. Poppenga, ${ }^{1}$ Jeffrey J. Danielson, ${ }^{1}$ Dean J. Tyler, ${ }^{1}$ \\ Dean B. Gesch, ${ }^{1}$ Maria Kottermair, ${ }^{2}$ Andrea Jalandoni, ${ }^{2}$ Edward Carlson, ${ }^{3}$ Cindy A. Thatcher, \\ and Matthew M. Barbee ${ }^{4}$
}

\section{Abstract}

Atoll and island coastal communities are highly exposed to sea-level rise, tsunamis, storm surges, rogue waves, king tides, and the occasional combination of multiple factors, such as high regional sea levels, extreme high local tides, and unusually strong wave set-up. The elevation of most of these atolls averages just under 3 meters $(\mathrm{m})$, with many areas roughly at sea level. The lack of high-resolution topographic data has been identified as a critical data gap for hazard vulnerability and adaptation efforts and for high-resolution inundation modeling for atoll nations (Helweg and others, 2014). Modern topographic survey equipment and airborne lidar surveys can be very difficult and costly to deploy. Therefore, unmanned aircraft systems (UAS) were investigated for collecting overlapping imagery to generate topographic digital elevation models (DEMs). Medium- and high-resolution satellite imagery (Landsat 8 and WorldView-3) was investigated to derive nearshore bathymetry.

The Republic of the Marshall Islands is associated with the United States through a Compact of Free Association, and Majuro Atoll is home to the capital city of Majuro and the largest population of the Republic of the Marshall Islands. The only elevation datasets currently available for the entire Majuro Atoll are the Shuttle Radar Topography Mission (SRTM) and the Advanced Spaceborne Thermal Emission and Reflection Radiometer (ASTER) Global Digital Elevation Model Version 2 (GDEM V2) elevation data, which have a 30-m grid-cell spacing and a 8-m vertical root mean square error (RMSE). Both these datasets have inadequate spatial resolution and vertical accuracy for inundation modeling.

The final topobathymetric DEM (TBDEM) developed for Majuro Atoll is derived from various data sources including charts, soundings, acoustic sonar, and UAS and satellite imagery spanning over 70 years of data collection (1944 to 2016) on

\footnotetext{
${ }^{1}$ U.S. Geological Survey.

${ }^{2}$ University of Guam.

${ }^{3}$ National Oceanic and Atmospheric Administration.

${ }^{4}$ University of Hawaii.
}

different sections of the atoll. The RMSE of the TBDEM over the land area is $0.197 \mathrm{~m}$ using over 70,000 Global Navigation Satellite System (GNSS) real-time kinematic (RTK) survey points for validation, and $1.066 \mathrm{~m}$ for Landsat 8 and $1.112 \mathrm{~m}$ for WorldView-3 derived bathymetry using over 16,000 and 9,000 lidar bathymetry points, respectively.

\section{Background}

The objective of the project is to collect survey-grade elevation data on Majuro Atoll (fig. 1) to create a topographic digital elevation model (DEM) with a 1-meter (m) horizontal resolution and at least $0.30-\mathrm{m}$ vertical root mean square error (RMSE) to support inundation modeling, marine and coastal resource management, and hazard vulnerability and adaptation efforts. The geographic scope of the project covers the southern half of Majuro Atoll, from Rita, Djarrit, Uliga, and Delap on the east to Laura on the west (fig. 1).

The Republic of the Marshall Islands is located in the northwest equatorial Pacific and consists of 29 atolls and 5 islands. The Marshall Islands are arranged in two island chains running roughly north-northwest to south-southeast, the western Ralik Chain and the eastern Ratak Chain; with exceptions being the Enewetak and Ujelang Atolls to the northwest that do not follow this alignment (U.S. Army Corps of Engineers, 1989; Spennemann, 1992). Majuro Atoll is home to more than half of the entire Marshall Islands population and continues to see rapid growth with a population density of 2,860 people per square kilometer $\left(\mathrm{km}^{2}\right)$ (Republic of Marshall Islands, Economic Policy, Planning, and Statistics Office, 2012). On average, the elevation of Majuro Atoll is $1.80 \mathrm{~m}$ above sea level, with the highest natural elevation of approximately $3.5 \mathrm{~m}$ above sea level occurring to the west in the Laura region (Palaseanu-Lovejoy and others, 2017a).

The Majuro Atoll topobathymetric digital elevation model (TBDEM) development is a collaboration between the U.S. Geological Survey (USGS) Coastal National Elevation Database (CoNED) Applications Project, the U.S. Department of Interior (DOI) Pacific Islands Climate Science Center (PI-CSC), the USGS Coastal and Marine Geology Program (CMGP), the University of Guam, the University of Hawaii at Mânoa, 


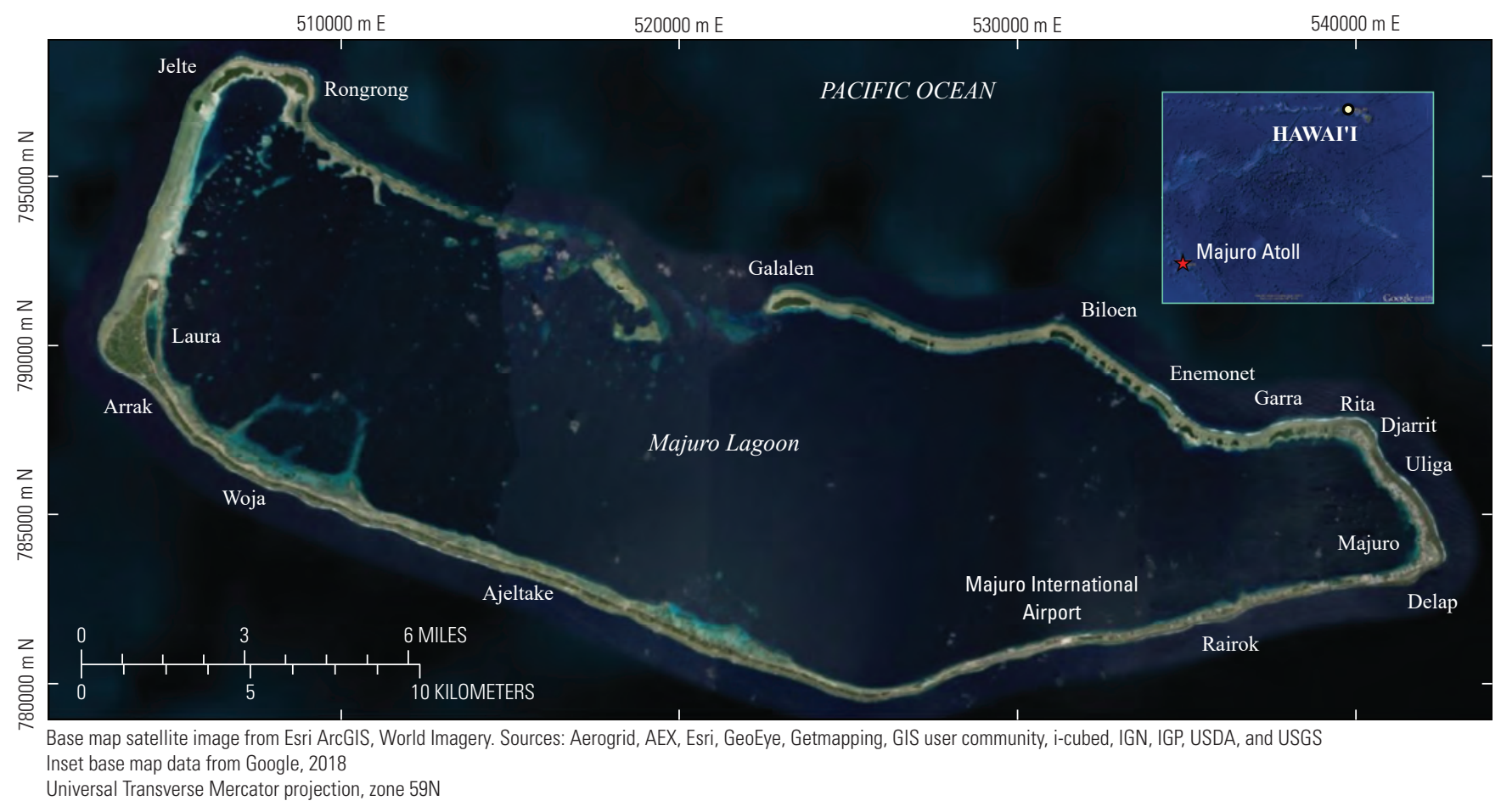

Figure 1. Map showing the location of Majuro Atoll, Republic of the Marshall Islands. Majuro Atoll is located approximately 3,800 kilometers southwest of Hawaii. Majuro, the capital of the Republic of the Marshall Islands, is located at UTM coordinates of approximately 542019.05 meters (m) Easting and 783693.85 m Northing, zone 59N (lat. 7.089806 N., long. 171.380502 E.).

Abbreviations: E, easting; GIS, geographic information systems; N, north or northing; USDA, United States Department of Agriculture; USGS, United States Geological Survey; UTM, Universal Transverse Mercator.

the National Oceanic and Atmospheric Administration (NOAA) National Geodetic Survey (NGS), the Republic of the

Marshall Islands Office of Lands and Survey, the College of the Marshall Islands, the Directorate of Civil Aviation Republic of the Marshall Islands, and the Marshall Islands Conservation Society. The CoNED Applications Project integrates disparate topographic and bathymetric data sources into a common 3D elevation database aligned both vertically and horizontally to a common reference system (Thatcher and others, 2016). The CoNED Applications Project provides a seamless elevation product that is required for several science application studies, such as shoreline delineation, coastal inundation mapping, sediment transport, sea-level rise, storm surge models, tsunami impact assessment, and vulnerability assessment. The data are utilized by the scientific and resource management communities for global change research, hydrologic modeling, resource monitoring, and mapping and visualization applications.

For many residents of the Republic of the Marshall Islands, long periods of severe drought combined with episodic extreme inundation events are daily realities. Inundation is due to more frequent king tide (unusual highest high tide) episodes, typhoons, and high storm surge exacerbated by a mixture of multiple factors such as high regional sea levels, extreme high local tides, and unusually strong wave set-up. The government and local population are extremely invested in hazard vulnerability analysis and adaptation, as well as marine and coastal resources management. Many residents express similar sentiments about their identity and culture being tied to the land; they cannot imagine abandoning the place where generations of their families have lived.

The only continuous elevation dataset currently available for Majuro Atoll is the Shuttle Radar Topography Mission (SRTM) data, which has a $30-\mathrm{m}$ grid-cell spacing and 16-m vertical accuracy (expressed as linear error at 90 percent confidence level). The goal of this project is to provide a high-resolution topographic DEM (1-m resolution) with a minimum vertical RMSE of $0.30 \mathrm{~m}$. An important objective is to generate baseline data for visualizing and mapping surficial geomorphologic features to enable analysis of the impact of extreme inundation events on atoll geomorphology and fresh groundwater lenses. This will facilitate a better understanding of the geomorphic dynamics and the processes controlling the development and changes of atoll landforms.

The final TBDEM developed for Majuro Atoll is derived from various data sources, including bathymetric charts and soundings, and unmanned aircraft systems (UAS) and satellite imagery. Collectively, these data sources span over 70 years of data collection (1944 to 2016) on different sections of Majuro Atoll. The RMSE of the TBDEM over the land area is $0.197 \mathrm{~m}$ using over 70,000 Global Navigation Satellite System (GNSS) real-time kinematic (RTK) survey points for validation, and $1.066 \mathrm{~m}$ and $1.112 \mathrm{~m}$ for bathymetry derived from Landsat 8 (L8) and WorldView-3 (WV-3) using over 16,000 and 9,000 lidar bathymetry points, respectively. 


\section{Technical Summary}

The methodology used by CoNED was employed for developing the TBDEM for Majuro Atoll. This method is repeatable and logically consistent and assimilates topographic data (land elevation) and bathymetry (water depth) into a seamless coastal elevation model. The vertical datum transformations are standardized in a workflow that interweaves spatially consistent interpolation (gridding) techniques with a land/water boundary mask delineation approach. The outputs are stacked into a file storage system of mosaic datasets within an Environmental Systems Research Institute (Esri) ArcGIS geodatabase for efficient updating while maintaining current and updated spatially referenced metadata (Danielson and others, 2016).

\section{Local Geoid Model for Orthometric Heights}

A local geoid model was developed for Majuro Atoll, Republic of the Marshall Islands, by the NOAA and the NGS based on data at 128 surveyed control points. The geoid model was needed to convert elevations referenced to the ellipsoid (native coordinate system for GNSS data) to orthometric heights (referenced to local mean sea level [LMSL]). The pertinent data at each control point location were the difference in vertical coordinates between the leveled benchmark height (referenced to LMSL as measured at a local tide station) and the ellipsoid height (as measured by a GNSS survey system). The point value differences were gridded into a continuous surface at a $52.5-\mathrm{m}$ spatial resolution by empirical Bayesian kriging in ArcGIS. The resulting grid has values ranging from 29.7 to $30.8 \mathrm{~m}$. To convert ellipsoid height measurements to orthometric heights, the value of the geoid model at the point locations is subtracted from the ellipsoid height measurements.

\section{Topography Processing Component}

Majuro Atoll consists of 64 coral islets with 9.17 square kilometers $\left(\mathrm{km}^{2}\right)$ total land area and $295.05 \mathrm{~km}^{2}$ of lagoon area, although the distance from Rita/Djarrit in the east to Laura in the west is more than 46 linear kilometers. The widest part of the atoll is slightly more than $500 \mathrm{~m}$, but on average is 100 to $150 \mathrm{~m}$ wide with the narrowest part slightly more than $30 \mathrm{~m}$ wide (fig. 1). The elevation of Majuro Atoll averages slightly less than $2 \mathrm{~m}$ above mean sea level, with many areas roughly at mean sea level and frequently inundated at high tide.

During a 10-day field survey of Majuro Atoll, from September 16 to September 26, 2016, topographic data were acquired using a Trimble R8 to collect GNSS RTK survey points, a Trimble S6 Robotic Total Station for under canopy elevation data, and a DJI Phantom 4 Pro UAS to collect nadir photographs over the southern part of the atoll. Over 83,000 GNSS points were collected, including over 12,000 points on the grounds of the Majuro International Airport and 104 ground control points (GSP) (fig. 2). The GNSS survey points were collected with two rovers, one mounted to the top of a vehicle to obtain points along roads, and one with a backpack mount to acquire points on reef flats at low tide, on recreational parks and agricultural fields, and on beaches. From the total number of points, 14.6 percent were collected at the Majuro International Airport, 1 percenton reef flats and beaches, 3.2 percent on agricultural field and recreational areas, and the rest ( 81.2 percent) were collected on roads. The survey points were collected with a Trimble system with an RMSE of $0.03 \mathrm{~m}$ (Trimble Navigation Limited, 2008).

The structure-from-motion (SfM) data were processed each day taking into consideration the contiguous geographical extent because the total number of photographs (over 20,000) to be processed at once exceeded the capabilities of the computer used. Therefore, the data collected each day were processed separately, generating 10 different point clouds that were classified and gridded to create bare-earth DEMs.

The nadir photographs were processed using the SfM methodology to generate a $3 \mathrm{D}$ point cloud. SfM estimates the $3 \mathrm{D}$ coordinates of easily identifiable points on an object from a set of multiple overlapping and offset 2D images taken from different viewpoints around that object (Westoby and others, 2012). Common points that are identified and matched on overlapping images are used to estimate relative camera positions. The 3D position of any given point on an object is obtained by triangulating the line of sight between different camera locations and the identified point under consideration. The initial 3D position is refined by iteratively minimizing the geometric error, the projection accuracy error (a relative assessment of matched point accuracy compared to the best matched points), and the reprojection error (differences between the modeled camera locations using the $3 \mathrm{D}$ point locations and the real camera locations). A dense $3 \mathrm{D}$ point cloud is derived from the sparse $3 \mathrm{D}$ point cloud using the "clustering views for multi-view stereo" (CMVS) algorithm and the "patch-based multi-view stereo" (PMVS2) algorithm (Furukawa and Ponce, 2007; Furukawa and others, 2010). The resulting dense $3 \mathrm{D}$ point cloud has a significant increase in point density, usually close to or exceeding two orders of magnitude of the sparse 3D point-cloud point density.

During the 10-day field work period, 21,877 nadir photographs were acquired using a DJI Phantom 4 UAS with 70 to 75 percent overlap and side lap. From these, 19,792 photographs were used in the 3D point-cloud reconstruction using the SfM methodology implemented in Agisoft PhotoScan (fig. 3). The generalized SfM workflow consists of several steps including the following: feature detection, keypoints matching, keypoints filtering, and the generation of the sparse 3D point cloud. The data is georeferenced using ground control points and the dense $3 \mathrm{D}$ point cloud is created. The last step is the classification of the $3 \mathrm{D}$ point cloud. The final $3 \mathrm{D}$ point cloud is the basis for further $3 \mathrm{D}$ reconstructions. 


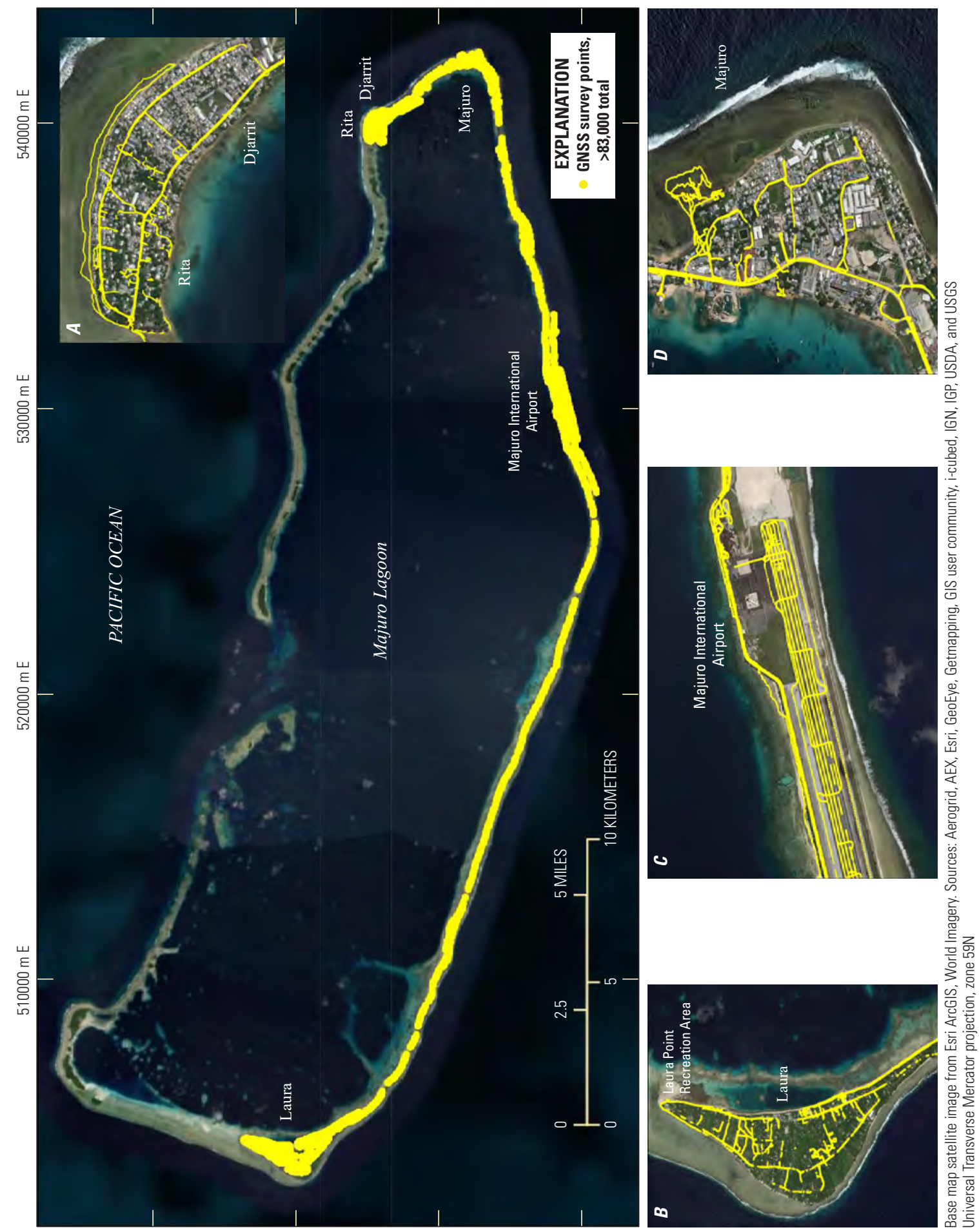

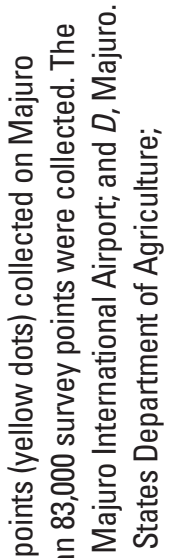
离要 竞心志

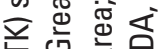
少的定鸟 .들 흘

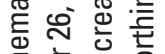
言 㐫

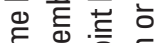
言 कृ ब을 क्ये $\sum_{\bar{\alpha}}^{\infty}$ 을 을 E फे के ब 壱 के के 我 क 引ํㅡㅁ음

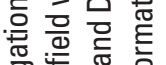
뭉 茂 焉

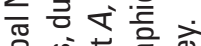
음 突䒕 흏 응

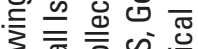

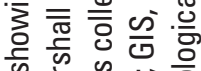
के

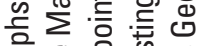
훟용 实范要焉 응 它山它

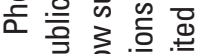
ง $\frac{0}{0} \frac{0}{5} \cdot \frac{\pi}{2}$ 닌 क्षे

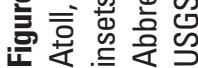




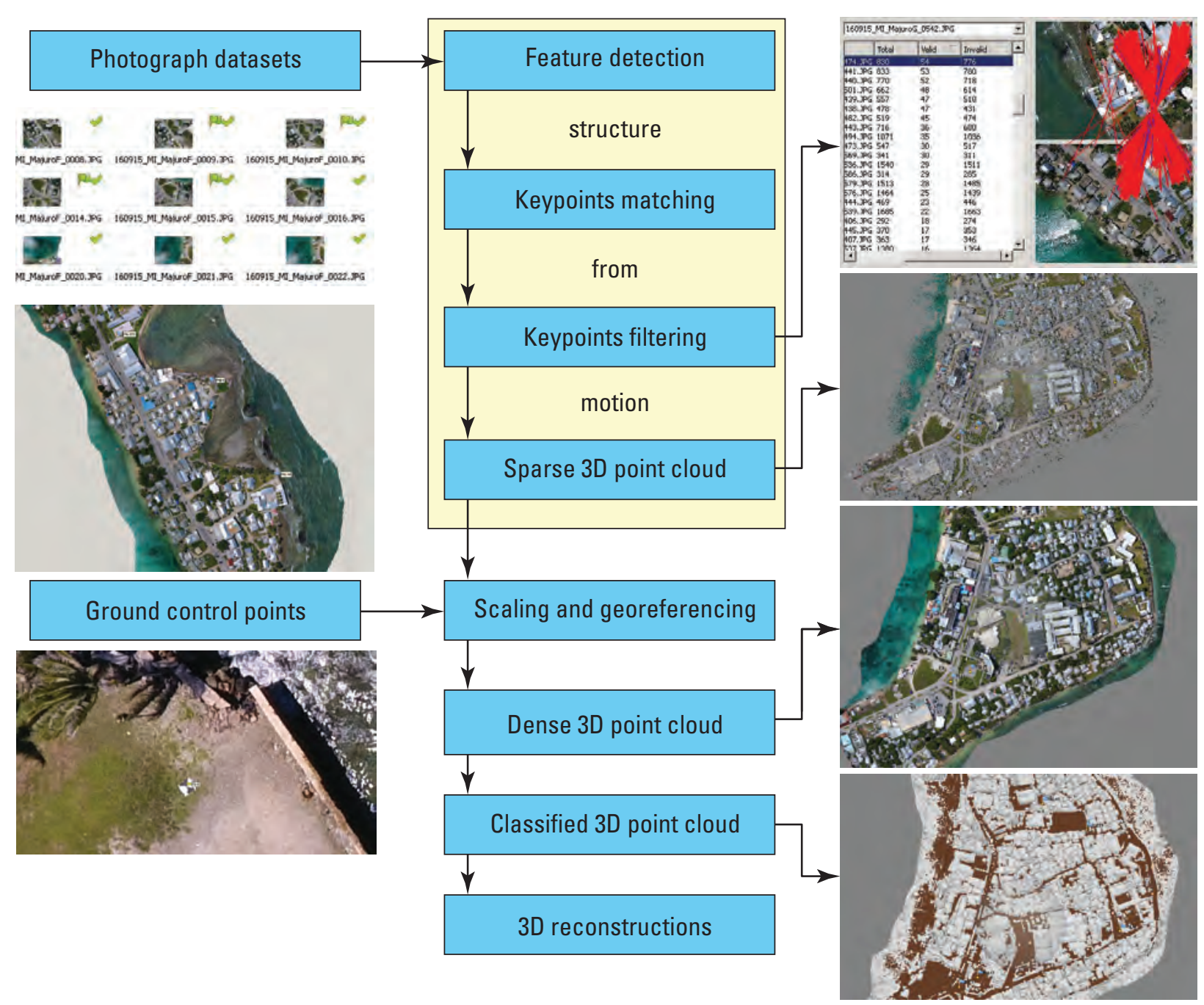

Figure 3. Diagram showing the typical workflow to derive georeferenced dense $3 D$ point clouds using structure-from-motion (SfM) algorithms implemented in Agisoft PhotoScan. The left column from top to bottom shows an example of unmanned aircraft systems (UAS) photographs (top left, photograph datasets), an example of a dense 3D point cloud (middle left), and an example of a UAS photograph with a target in it (bottom left). The middle column illustrates the key components of the SfM methodology workflow (top to bottom), and the right column shows examples of the SfM methodology workflow including: keypoints filtering, a sparse 3D point cloud, a dense 3D point cloud, and a classified 3D point cloud. In the top right, as a demonstration, the matches determined to be valid between two photographs are shown in blue, while matches determined to be invalid are shown in red. Workflow adapted from Smith and others (2016). Images generated using point cloud data.

The sparse point cloud data has a reconstruction uncertainty (geometric error) no greater than 10 times the smallest error, a projection accuracy error no greater than 5 times the smallest accuracy error, and a reprojection error less than 0.3 pixels. Onemeter square targets placed in the field of view of the camera were used as ground control points to georeference the SfM 3D point cloud data (fig. 3). The dense 3D point cloud was automatically classified in Agisoft PhotoScan into two classes, ground points (bare earth) and unclassified (vegetation, buildings, water, and noise) points. This classification was further manually and iteratively refined to derive a bare-earth DEM using the interpolation method described by Danielson and others (2016).
Both the resulting 3D point cloud and the topography DEM were validated using more than 70,000 GNSS points.

Both the interpolated bare-earth DEM and the derived 3D point cloud were validated against the GNSS points. In the case of the 3D point cloud, we used the Multiscale Model-to-Model Cloud Comparison (M3C2) method implemented in CloudCompare and described by Lague and others (2013). This method eliminates the need for meshing or gridding and computes the local distance between two point clouds in a cylindrical neighborhood along the normal surface direction to track 3D variations in surface orientation (Lague and others, 2013). That translates into defining a search neighborhood whose axis 
goes through point $i$ and is parallel with the normal vector $N$ for each point $i$ of the GNSS points. To speed the calculations, a fixed diameter and height are defined for the cylindrical search neighborhood. The intersection of this search neighborhood with the two point clouds identifies two subsets of points of size $n 1$ (light blue points, fig. 4) and $n 2$ (pink points, fig. 4). The average position of the cloud subsets along the normal direction is calculated by averaging all the distances between the GNSS point $i$ and each of the point-cloud point projections on the normal vector $N$. The local distance between the two point clouds $\mathrm{L}_{\mathrm{M} 3 \mathrm{C} 2}(\mathrm{i})$ is then given by the distance between the two projected means (Lague and others, 2013) (fig. 4).

Because all GNSS points were measurements of bare ground, the cylindrical search neighborhood had a diameter of $1 \mathrm{~m}$ and a height of 1 to $1.5 \mathrm{~m}$, which minimized any nonground point influences in the non-classified, point cloud neighborhood used for validation. Of 71,373 GNSS points, 69,648 (97.5 percent) had SfM point-cloud points within $1 \mathrm{~m}$ of each GNSS point location.

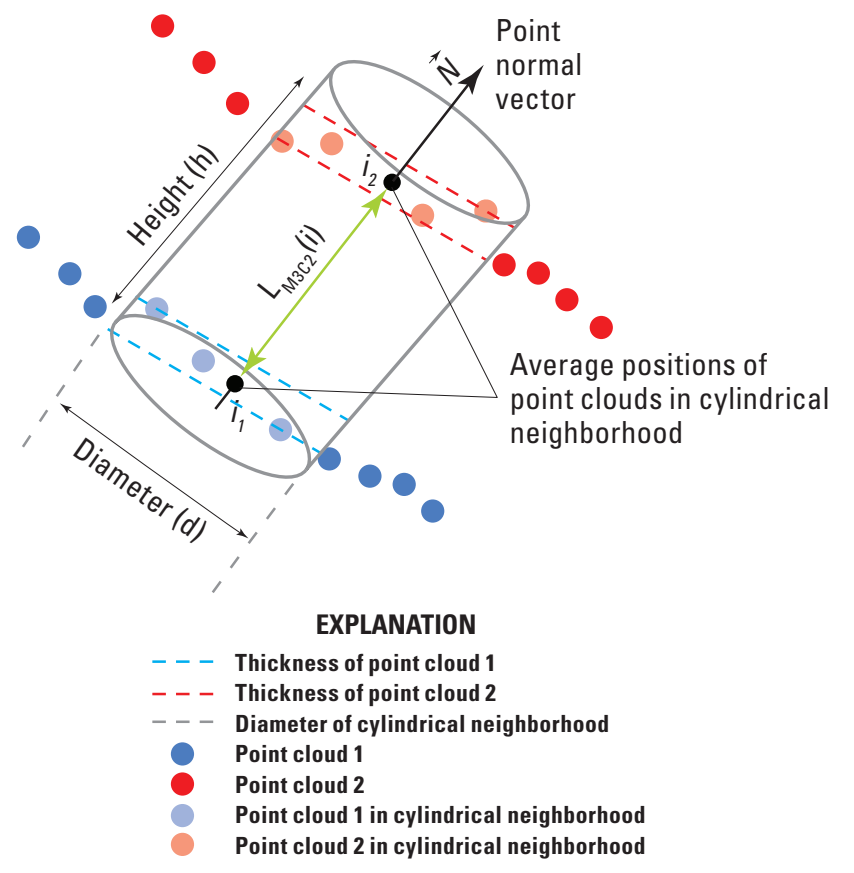

Figure 4. Diagram illustrating the Multiscale Model-to-Model Cloud Comparison (M3C2) principle. The blue and red dots represent the two different point clouds, while the light-blue and pink dots are the respective point clouds inside the cylindrical neighborhood. The blue and red dashed lines represent the thickness of respective point clouds inside the cylindrical neighborhood. The cylindrical neighborhood has a diameter " $d$ " (dashed gray lines) and a height " $h$ " and its axis is parallel with the point normal vector $\vec{N}$. The black dots $i_{1}$ and $i_{2}$ represent the average positions of the two point-cloud subsets on the normal vector $\vec{N}$. The distance $\mathrm{L}_{\mathrm{M} 32}(\mathrm{i})$ between the two point clouds within the cylindrical neighborhood is the distance between $i_{1}$ and $i_{2}$.

\section{Bathymetry Processing Component}

\section{Satellite-Derived Bathymetry}

Satellite-derived bathymetry (SDB) remote sensing research utilizes ocean optics to estimate nearshore bathymetry elevation values using satellite imagery acquired from satellites such as Landsat 8 (L8) or DigitalGlobe WorldView-3 (WV-3) platforms. Coastal, blue, green, and infrared channels are used to derive band-ratio elevation profile estimates, commonly known as the "natural logarithm approach." These SDB methods have been published by Pe'eri and others (2013) and the International Hydrographic Organization, Intergovernmental Oceanographic Commission (2015).

The L8 multispectral bands (U.S. Geological Survey, 2016) (https://earthexplorer.usgs.gov/) used in the SDB process were coastal band $1(0.433-0.453$ microns $[\mu \mathrm{m}])$, blue band 2 $(0.450-0.515 \mu \mathrm{m})$, green band $3(0.525-0.600 \mu \mathrm{m})$, red band 4 $(0.630-0.680 \mu \mathrm{m})$, and the shortwave infrared (SWIR) band 6 $(1.566-1.651 \mu \mathrm{m})$. The WV-3 atmospherically corrected (using the DigitalGlobe Atmospheric Compensation [ACOMP] alogrithm) 16-bit multispectral imagery were obtained from DigitalGlobe (DigitalGlobe, 2016) (https://www.digitalglobe.com/), and the bands used in the SDB process were blue band $2(0.45-0.51 \mu \mathrm{m})$, green band $3(0.51-0.58 \mu \mathrm{m})$, and the near-infrared (NIR2) band $8(0.86-1.04 \mu \mathrm{m})$. Esri ArcMap and Harris Geospatial Environment for Visualizing Images (ENVI) software were used to subset and process the L8 and WV-3 imagery to the Majuro Atoll extent. Both L8 and WV-3 raw imagery values were converted to floating point values, after which a low-pass filter was applied to eliminate outlier values (Poppenga, 2017).

An inflection point was determined on a spectral response curve between the land and water using the L8 shortwave infrared band 1 (SWIR-1) $(1.57-1.65 \mu \mathrm{m})$ and WV-3 NIR2 band $8(0.86-1.04 \mu \mathrm{m})$ to mask out the land portion of the study area. Subsequent SDB processing was applied only to the water areas delineated in this initial step. The land portion of the study area was masked out using the L8 SWIR-1 band and the WV-3 NIR2 band inflection point values for each L8 or WV-3 band ratio (for L8, the band ratio is blue/green or coastal/red; for WV-3, the band ratio is blue/green).

SDB profile estimates were derived from the band ratios of both the blue band to green band and the coastal band to red band for L8, and for WV-3 the estimation was done from the blue band to green band ratio. The resulting values represent relative SDB estimates that need to be calibrated to obtain actual depth values. Bathymetric lidar obtained from the Naval Oceanographic Office (NAVOCEANO) (Naval Oceanographic Office, 2006a) was released to the USGS for SDB calibration purposes only. Because the bathymetric lidar was only available in the Calalin Channel in the middle northern part of the atoll, satellite imagery was used to derive nearshore bathymetric estimates. The bathymetric lidar values less than the extinction depth or the optical depth (for inferring bathymetry) were used as control points. A linear 
regression was performed between the bathymetric lidar elevation values and the SDB estimates. The SDB estimates were then calibrated by means of an affine transformation using the obtained regression line, and the optically deep values beyond the estimated extinction depth were removed. To achieve a consistent datum with the topographic part of the Majuro Atoll TBDEM, the SDB estimates were adjusted from chart or bathymetric lidar values (mean low water springs [MLWS]) to map datum (mean sea level [MSL]) by applying an adjustment value of $1.022 \mathrm{~m}$ derived from the Majuro International Airport benchmark tied to the local tidal benchmark (Naval Oceanographic Office, 2006b).

The vertical and horizontal datum and projection information of the input bathymetric source datasets were checked to ensure the data were referenced to MSL and the Universal Transverse Mercator (UTM) zone 59 north (N) projection.

\section{Bathymetry Derived From Charts and Sonar Surveys}

The Secretariat of the Pacific Community (SPC) Pacific Islands Applied Geoscience Commission (SOPAC) carried out a marine survey for Majuro Atoll (both the lagoon and parts of offshore) in the Marshall Islands using a multibeam echo sounder (or sonar) (MBES) (Kruger and Kumar, 2008). This work was part of the project "Reducing Vulnerability of Pacific States" funded by the European Development Fund. The survey accomplished good coverage of the sea floor in the lagoon from approximately 10 to $70 \mathrm{~m}$ water depths. The data in the lagoon supported a raster resolution of $5 \mathrm{~m}$. The eastern nearshore area of the reef slope was mapped to an average offshore distance of $5 \mathrm{~km}$, from approximately $10-\mathrm{m}$ depth to over 2,000-m depth, and gridded at 50-m resolution. The survey data were supplemented with data previously collected by SOPAC in 2003 (Kruger and Kumar, 2008; SPC Geosciences, Secretariat of the Pacific Islands Applied Geoscience Commission [SOPAC], 2008).

An airborne hydrographic survey using Compact Hydrographic Airborne Rapid Total Survey (CHARTS) was conducted off the Majuro Calalin Channel, Republic of the Marshall Islands, by the NAVOCEANO (Naval Oceanographic Office, 2006a, b). All soundings and elevations were collected referenced to the World Geodetic System of 1984 (WGS 84) ellipsoid and were transformed to be vertically referenced to MLWS. The CHARTS bathymetric lidar points were only used in the calibration and validation of SDB, and raw bathymetric elevations were not included in the TBDEM model.

Parts of the shallow lagoon bathymetry, as well as offshore bathymetry on the western half of the atoll, were obtained from the Majuro Atoll Digital Nautical Chart 12, U.S. Navy Surveys of 1944 and 2006 (National GeospatialIntelligence Agency, Maritime Safety Office, 2017).

\section{TBDEM Integration}

The principal methodology for developing the integrated TBDEM is organized into three main components including topography, bathymetry, and integration (Danielson and others, 2016). The topography component consists of the land-based elevation data derived from the high-resolution nadir imagery acquired by a UAS using SfM methodology (Palaseanu-Lovejoy and others, 2017a, b). The bathymetry component consists of generating SDB estimates (Pe'eri and others, 2013) from USGS L8 imagery (U.S. Geological Survey, 2016), DigitalGlobe WV-3 imagery (DigitalGlobe, 2016), hydrographic soundings and chart vectors (National Geospatial-Intelligence Agency, Maritime Safety Office, 2017), and multibeam acoustic sonar (Kruger and Kumar, 2008). The most common forms of bathymetry used in this model include SDB derived from USGS L8 and DigitalGlobe WV-3 imagery (Pe'eri and others, 2013), multibeam, and chart vector product format. The final integration component involves the assimilation of the topographic and bathymetric data along the nearshore based on a predefined set of priorities. The land/water interface $(+1.0 \mathrm{~m}$ to $-1.5 \mathrm{~m})$ is the most critical area. The end product from the topography and bathymetry components is a raster with associated spatial masks and metadata that are passed to the integration component for final model generation.

The integration component was performed within Esri ArcGIS, developing a geodatabase mosaic dataset to create an integrated seamless TBDEM composite at a 1-m cell size. This process included generating spatial seamlines for each individual layer of the TBDEM, including the topographic SfM raster dataset and bathymetric raster datasets (SOPAC, SDB, and chart soundings). To minimize interpolation artifacts, the priority of input topographic SfM and bathymetric SOPAC, SDB, and chart sounding data were determined based on a variety of project data requirements, such as quality, age, accuracy, and coverage. This method uses an iterative finite-difference interpolation technique that optimizes the computational efficiency of local interpolation methods without losing surface continuity. Seamline edges were generated to smooth transition boundaries between neighboring raster layers and to split complex raster datasets with isolated regions into individual unique raster groups. Using spatial weighting over a distance of five pixels to prevent losing detail in narrow features, a shoreline transition zone was developed by integrating the best available topographic and bathymetric data. A visual quality assurance assessment was performed on the output composite to review the mosaic seams for artifacts. Spatially referenced metadata consisting of polygon footprints that represent each TBDEM source input dataset were generated. The spatial metadata include attributes that describe the source dataset name, source organization, source project, source data resolution, acquisition date, source publication, and topographic or bathymetric data type (fig. 5). 

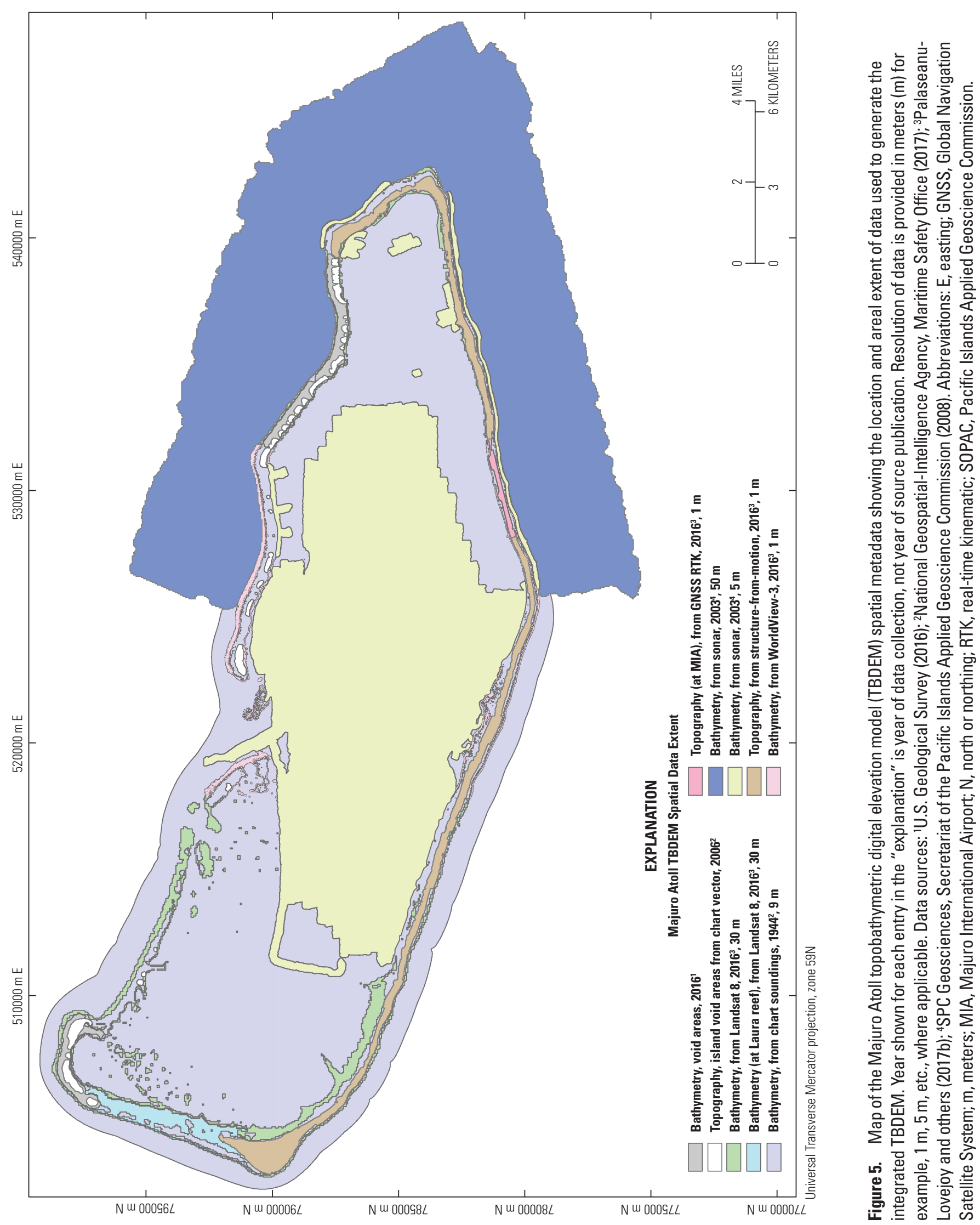
Accuracy assessments were conducted for the SDB and SfM components using the CHARTS bathymetric lidar and the GNSS points, respectively. The position errors between the measured values and the estimated values were described using the mean error (ME), mean absolute error (MAE), and root mean square error (RMSE). The ME indicates if there is any bias in the data, the MAE represents the average magnitude of the errors without considering their direction, and the RMSE penalizes large errors more than the others, since RMSE increases with the variance of the frequency distribution of error magnitudes.

\section{Results}

The final Majuro Atoll TBDEM incorporates the bare-earth DEM (topography) from Rita in the east to Laura in the west (at 1-m resolution) with lagoon bathymetry $\left(295 \mathrm{~km}^{2}\right.$ area) and offshore ocean bathymetry up to $1 \mathrm{~km}$ on the western half and over $4 \mathrm{~km}$ on the eastern half of the atoll (fig. 6). The project investigated the utility of SfM methods and UAS-collected imagery to generate high-resolution topographic DEMs over large areas. It also investigated the derivation of nearshore bathymetry data from medium- and high-resolution satellite imagery. The resulting bathymetry is a compilation of different charts and soundings collected over 70 years, from 1944 to 2006, coupled with satellite-derived nearshore bathymetry.

The SfM 3D point cloud was georeferenced using 104 ground control points on aerial targets with an average spacing between them of $400 \mathrm{~m}$. The RMSEs of the dense 3D point cloud in relation to the ground control points for easting and northing coordinates are 0.245 and $0.121 \mathrm{~m}$, respectively, and $0.040 \mathrm{~m}$ for vertical coordinates. Error metrics are presented in table 1.

Using only the ground classified points from the SfM 3D point cloud, a bare-earth DEM was derived at 1-m resolution using the methodology described by Danielson and others (2016). We used the rest of the GNSS points as previously used to calculate different error measurments for validation (table 2). The error distance between the GNSS points to the $3 \mathrm{D}$ point cloud was computed using the $\mathrm{M} 3 \mathrm{C} 2$ methodology described by Lague and others (2013).

Bathymetry derived from L8 and WV-3 was validated against the CHARTS bathymetric lidar points (Naval Oceanographic Office, 2006a, b) that were not used for SDB calibration. The results are presented in table 3 .
Table 1. Error metrics using ground control points.

[Abbreviations: m, meters; RMSE, root mean square error]

\begin{tabular}{lccc}
\hline $\begin{array}{c}\text { Targets (104 ground } \\
\text { control points) }\end{array}$ & $\begin{array}{c}\text { X coordinate } \\
\text { (east) }\end{array}$ & $\begin{array}{c}\text { Y coordinate } \\
\text { (north) }\end{array}$ & $\begin{array}{c}\text { Z coordinate } \\
\text { (altitude) }\end{array}$ \\
\hline Mean error $(\mathrm{m})$ & 0.000 & 0.000 & 0.000 \\
Mean absolute error $(\mathrm{m})$ & 0.107 & 0.073 & 0.029 \\
RMSE $(\mathrm{m})$ & 0.245 & 0.121 & 0.040 \\
\hline
\end{tabular}

Table 2. Validation measurements results using Global Navigation Satellite System (GNSS) points.

[Abbreviations: DEM, digital elevation model; m, meters; RMSE, root mean square error; SfM, structure from motion]

\begin{tabular}{lcccc}
\hline & $\begin{array}{c}\text { Number } \\
\text { of points }\end{array}$ & $\begin{array}{c}\text { Mean } \\
\text { error }(\mathbf{m})\end{array}$ & $\begin{array}{c}\text { Mean absolute } \\
\text { error }(\mathbf{m})\end{array}$ & $\begin{array}{c}\text { RMSE } \\
(\mathbf{m})\end{array}$ \\
\hline $\begin{array}{c}\text { SfM 3D point } \\
\text { cloud }\end{array}$ & 69,648 & 0.053 & 0.145 & 0.191 \\
$\begin{array}{c}\text { Bare-earth DEM } \\
(1-m \text { resolution) }\end{array}$ & 71,373 & 0.009 & 0.144 & 0.197 \\
\hline
\end{tabular}

Table 3. Validation measurements results for satellite-derived bathymetry (SDB) using Compact Hydrographic Airborne Rapid Total Survey (CHARTS) lidar data.

[Landsat 8 (L8) acquired at nadir on March 1, 2016; WorldView-3 (WV-3) imagery acquired on January 30, 2016, and atmospherically corrected with mean off-nadir angle of 13.9 degrees. Abbreviations: m, meters; RMSE, root mean square error]

\begin{tabular}{ccccc}
\hline & $\begin{array}{c}\text { Number } \\
\text { of points }\end{array}$ & $\begin{array}{c}\text { Mean } \\
\text { error }(\mathbf{m})\end{array}$ & $\begin{array}{c}\text { Mean absolute } \\
\text { error }(\mathbf{m})\end{array}$ & $\begin{array}{c}\text { RMSE } \\
(\mathbf{m})\end{array}$ \\
\hline $\begin{array}{c}\text { L8 SDB blue/ } \\
\text { green band ratio }\end{array}$ & 16,941 & 0.947 & 0.980 & 1.065 \\
$\begin{array}{c}\text { L8 SDB coastal/ } \\
\text { red band ratio }\end{array}$ & 3,090 & 0.285 & 1.408 & 1.478 \\
$\begin{array}{c}\text { WV-3 SDB blue/ } \\
\text { green band ratio }\end{array}$ & 9,632 & 0.866 & 0.919 & 1.112 \\
\hline
\end{tabular}




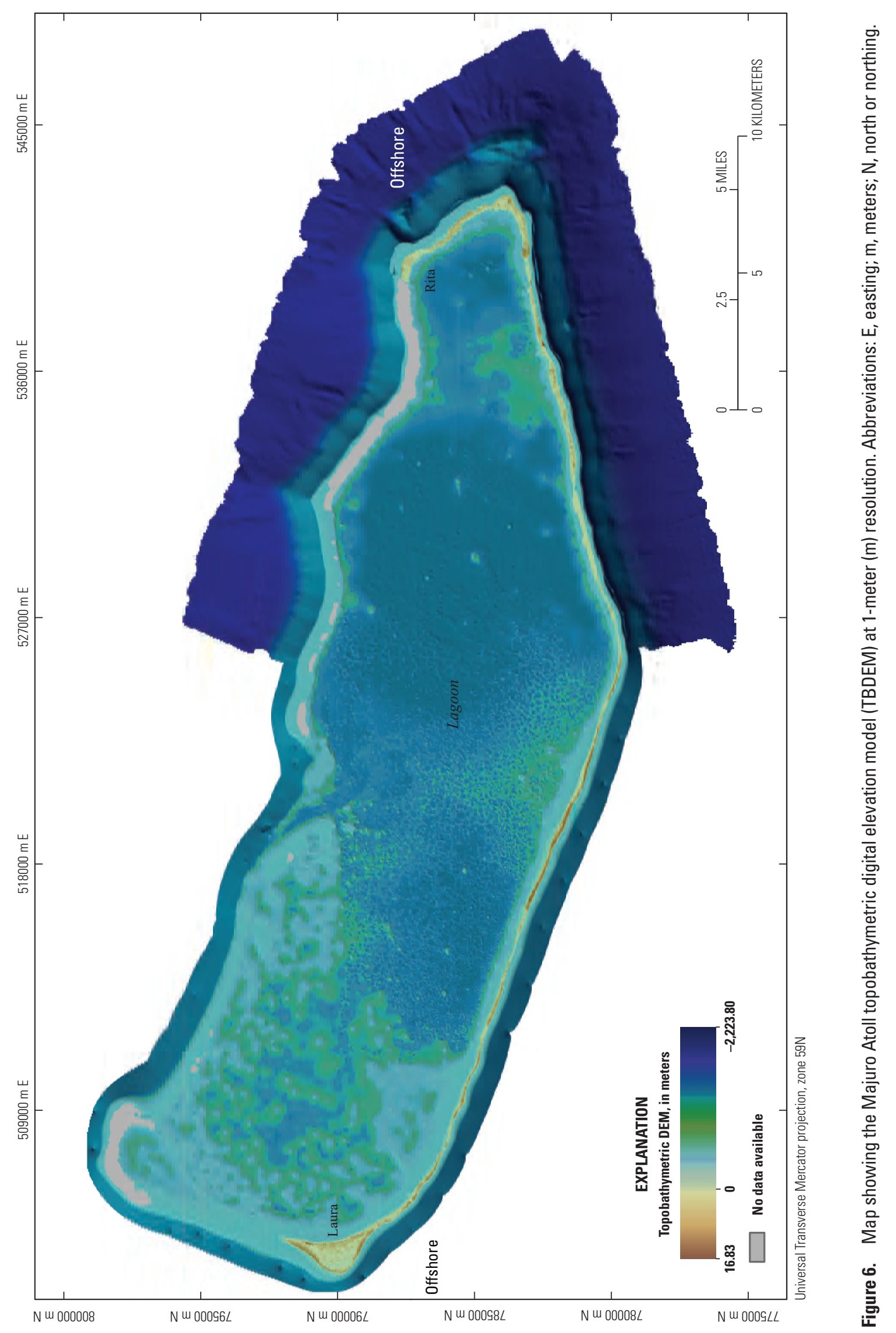




\section{Analysis and Findings}

Because of the narrow and elongated rectangular geometric shape of the surveyed area, a "bowl" distortion effect was observed in both the 3D point cloud data and the derived DEM at the narrow edges of the surveyed area of each field work day. To overcome this effect, for any two adjacent rasters (results of two different field work days), the raster determined to be the less accurate was adjusted toward the more accurate one. The adjustment occurred in the overlap area between the closest ground control point to that edge (which was not adjusted at all) and that respective edge. This was done in an iterative trial-observe-adjust fashion, using a first-order polynomial trend surface created to re-adjust the original surface beyond the last ground control point, making sure that the two adjacent rasters joined seamlessly. The adjustment surfaces did not introduce more errors into the topographic DEM because the error measures for both the $3 \mathrm{D}$ point cloud and the integrated bare-earth DEM are similar (table 2). Furthermore, the DEM had almost no bias in comparison with the approximately 70,000 GNSS validation points collected on the atoll roads, agricultural and recreational fields, and beaches.

This was one of the largest areas (over $20 \mathrm{~km}^{2}$ ) surveyed to date using a commercial light UAS in a tropical coastal community with data processed at decimeter accuracy and centimeter precision. Previous available data for the region had decameter accuracy. From the validation results, the RMSE for the topographic part of the Majuro Atoll TBDEM is $0.197 \mathrm{~m}$, which translates to $\pm 0.386 \mathrm{~m}$ accuracy at 95 percent confidence level (Maune and others, 2007). The atoll has a small topographic range, with the highest natural elevation of $+3.5 \mathrm{~m}$ above LMSL on the west side, although a manmade infrastructure (bridge) and gravel/sand heaps are up to $+16.8 \mathrm{~m}$ LMSL.

There is a positive bias in the SDB data of $0.947 \mathrm{~m}$ for the $\mathrm{L} 8 \mathrm{blue} / \mathrm{green}$ band ratio, $0.285 \mathrm{~m}$ for the $\mathrm{L} 8$ coastal/red band ratio, and $0.866 \mathrm{~m}$ for the WV-3 blue/green band ratio. The L8 blue/green band ratio was used to derive bathymetry for most of the atoll lagoon to depths of up to $6 \mathrm{~m}$, whereas the $\mathrm{L} 8$ coastal/red band ratio was better suited for deriving the bathymetry over the reef flats north of Laura. The WV-3 blue/ green band ratio was used for the central part of the atoll near the shipping channel.

For bathymetry in general, the vertical accuracy depends on water depth as well as water conditions such as waves, tides, and water clarity. Vertical accuracy also depends on errors introduced by the instrument and the mode of deployment. For the SDB (besides these mentioned sources of error), cloud cover, atmospheric conditions, and the off-nadir angle need to be considered as possible sources of error. All of these potential sources of errors may contribute to the positive bias in the SDB data. To further investigate the validation errors, the SDB data were split into two separate depth intervals including (1) 0 to $4 \mathrm{~m}$, and (2) $4 \mathrm{~m}$ to the extinction depth ( $>4 \mathrm{~m}$ ) for the three SDB areas under consideration (table 4).
From the results shown in table 4, the L8-derived bathymetry has a bimodal distribution, while the WV-3derived bathymetry is positively biased for both depth intervals. Taking these results into consideration, a depthrelated adjustment to overcome the bias should be considered. From the limited SDB data, it is not clear if the adjustment is only depth dependent, or if it is location dependent as well. For this reason the SDB data were not further amended.

For single beam and multibeam surveys, vertical and horizontal accuracy have both a depth-dependent uncertainty and a constant one. According to the International Hydrographic Organization (2008), the vertical limits (minimum and maximum) of the total vertical uncertainty within which the uncertainty of the survey must fall (to comply with the standard) is computed at the 95 percent confidence level using the following formula:

$$
\pm \sqrt{a^{2}+(b \times d)^{2}}
$$

where

$$
\begin{array}{ll}
a & \text { is the constant portion of the uncertainty; } \\
b & \text { is the depth-dependent parameter; and } \\
d & \text { is the depth in meters. }
\end{array}
$$

The values of variables " $a$ " and " $b$ " vary with the type of area surveyed and water depth (see table 1 of International Hydrographic Organization, 2008).

Considering the equation and standards in table 1 of International Hydrographic Organization (2008), the SOPAC multibeam survey accuracy has the following horizontal and vertical limits (table 5). The inferred vertical accuracy is calculated using the following equation:

$$
\text { Accuracy }(95 \% \text { confidence })= \pm 1.96 \times R M S E
$$

where

RMSE is the root mean square error.

The CHARTS bathymetric lidar points (Naval Oceanographic Office, 2006a, b) accuracy is in compliance with the International Hydrographic Organization (IHO) "Orders 1a" and " $1 b$ " survey accuracy standards (see table 1 of International Hydrographic Organization, 2008).

The Majuro Atoll TBDEM, (1) has a 1-m resolution, (2) covers a total area of $599.6 \mathrm{~km}^{2}$, (3) is compliant with the IHO (2008) published standards of vertical accuracy for bathymetry, and (4) satisfies the USGS National Geospatial Program (NGP) lidar base specifications (Heidemann, 2014) for quality level 3 data for topography, which aligns with the American Society for Photogrammetry and Remote Sensing (American Society for Photogrammetry and Remote Sensing, 2015) 20-centimeter (cm) vertical RMSE class. The vertical RMSE for the topographic 3D point cloud is $19.1 \mathrm{~cm}$ and the vertical RMSE for the topographic DEM is $19.7 \mathrm{~cm}$. 
Table 4. Error metrics for the three different satellite-derived bathymetry (SDB) areas segmented by water depth.

[Abbreviations: CHARTS, Compact Hydrographic Airborne Rapid Total Survey; L8, Landsat 8; m, meters; \%, percent; RMSE, root mean square error; WV-3, WorldView-3]

\begin{tabular}{|c|c|c|c|c|}
\hline Depth & $\begin{array}{l}\text { Errors compared to } \\
\text { CHARTS lidar }\end{array}$ & $\begin{array}{l}\text { L8, nadir angle, } \\
\text { blue/green band ratio }\end{array}$ & $\begin{array}{l}\text { L8, nadir angle, } \\
\text { coastal/red band ratio }\end{array}$ & $\begin{array}{l}\text { WV-3, off-nadir } \\
\text { angle of } 13.9 \text { degrees, } \\
\text { blue/green band ratio }\end{array}$ \\
\hline \multirow[t]{5}{*}{ Overall } & Number of points & 16,941 & 3,090 & 9,632 \\
\hline & Area (\% of total) & 2.43 & 0.67 & 0.46 \\
\hline & Mean error (m) & 0.947 & 0.285 & 0.867 \\
\hline & Mean absolute error (m) & 0.980 & 1.408 & 0.919 \\
\hline & RMSE (m) & 1.065 & 1.478 & 1.112 \\
\hline \multirow[t]{4}{*}{0 to $4 \mathrm{~m}$} & Number of points & 801 & 125 & 1,239 \\
\hline & Mean error (m) & -0.199 & -0.913 & 1.253 \\
\hline & Mean absolute error (m) & 0.479 & 1.038 & 1.327 \\
\hline & RMSE (m) & 0.608 & 1.231 & 1.640 \\
\hline \multirow[t]{4}{*}{$>4 \mathrm{~m}$} & Number of points & 16,140 & 2,965 & 8,393 \\
\hline & Mean error (m) & 1.004 & 0.336 & 0.810 \\
\hline & Mean absolute error (m) & 1.005 & 1.423 & 0.859 \\
\hline & RMSE (m) & 1.082 & 1.488 & 1.011 \\
\hline
\end{tabular}

Table 5. Limits for accuracy and vertical root mean square error (RMSE) of the Pacific Islands Applied Geoscience Commission (SOPAC) data using International Hydrographic Organization (2008) standards.

[Abbreviation: $\mathrm{m}$, meters]

\begin{tabular}{|c|c|c|c|c|c|c|c|}
\hline Depth (m) & $10 \mathrm{~m}$ & $100 \mathrm{~m}$ & $101 \mathrm{~m}$ & $200 \mathrm{~m}$ & $500 \mathrm{~m}$ & $1,000 \mathrm{~m}$ & $2,000 \mathrm{~m}$ \\
\hline $\begin{array}{l}\text { Horizontal limits for accuracy } \\
\text { (95\% confidence) }\end{array}$ & $\pm 5.5 \mathrm{~m}$ & $\pm 10 \mathrm{~m}$ & $\pm 25.05 \mathrm{~m}$ & $\pm 30 \mathrm{~m}$ & $\pm 175 \mathrm{~m}$ & $\pm 200 \mathrm{~m}$ & $\pm 250 \mathrm{~m}$ \\
\hline $\begin{array}{l}\text { Vertical limits for accuracy } \\
\text { (95\% confidence) }\end{array}$ & $\pm 0.516 \mathrm{~m}$ & $\pm 1.392 \mathrm{~m}$ & $\pm 2.529 \mathrm{~m}$ & $\pm 4.707 \mathrm{~m}$ & $\pm 11.543 \mathrm{~m}$ & $\pm 23.021 \mathrm{~m}$ & $\pm 46.010 \mathrm{~m}$ \\
\hline $\begin{array}{l}\text { Inferred vertical limits for } \\
\text { RMSE }\end{array}$ & $0.263 \mathrm{~m}$ & $0.711 \mathrm{~m}$ & $1.290 \mathrm{~m}$ & $2.401 \mathrm{~m}$ & $5.889 \mathrm{~m}$ & $11.745 \mathrm{~m}$ & $23.475 \mathrm{~m}$ \\
\hline
\end{tabular}

\section{Conclusions and Recommendations}

There are approximately 500 atolls worldwide, with over 350 located in the Pacific and Indian Oceans providing shelter to more than 700,000 people (Spalding and others, 2001; Yamano and others, 2007; Yasukochi and others, 2014). Atoll and island coastal communities are extremely vulnerable to sea-level rise, tsunamis, storm surges, rogue waves, king tides, and the occasional combination of multiple factors such as high regional sea levels, extreme high local tides, and unusually strong wave set-up. The elevation of most of these atolls averages just less than 3 meters (m) above local mean sea level, with many areas roughly at sea level. The lack of high-resolution topographic data has been identified as a critical data gap for climate vulnerability and adaptation efforts and for high-resolution inundation modeling for atoll nations (Helweg and others, 2014). Modern topographic survey equipment and airborne lidar surveys can be very difficult and costly to deploy, thus, we investigated the usability of collecting overlapping imagery with commercial unmanned aircraft systems (UAS) (for example, DJI Phantom 4) to generate bare-earth digital elevation models (DEMs) and medium- and high-resolution satellite imagery (Landsat 8 [L8] and WorldView-3 [WV-3]) to derive bathymetry in nearshore tropical waters.

The final topobathymetric digital elevation model (TBDEM) for Majuro Atoll is derived from various data sources, from charts and soundings to UAS and satellite imagery, spanning over 70 years of data collection on different sections of Majuro Atoll, from 1944 to 2016, and covering an area of $599.6 \mathrm{~km}^{2}$. The goal of this research was to generate a $1-\mathrm{m}$ resolution bare-earth DEM of the southern portion of Majuro Atoll, from Rita in the east to Laura in 
the west, covering approximately $20 \mathrm{~km}^{2}$, to (1) provide a much needed baseline for inundation modeling, (2) natural hazards risk assessment, and (3) marine and coastal resource management. The incorporated lagoon and ocean bathymetry derived from historical lidar, charts, and soundings is in compliance with the International Hydrographic Organization (2008) published standards for vertical accuracy.

The topographic survey of Majuro Atoll is one of the largest areas (over $20 \mathrm{~km}^{2}$ ) acquired using a commercial light UAS in a tropical coastal community with data processed at decimeter accuracy and centimeter precision. In comparison, the only other available data, the Shuttle Radar Topography Mission (SRTM) and Advanced Spaceborne Thermal Emission and Reflection Radiometer (ASTER), have $30-\mathrm{m}$ grid cell spacing and 8 -m vertical root mean square error (RMSE), which are inadequate for inundation modeling. From the validation results, the RMSE for the topographic part of the Majuro Atoll TBDEM is $0.197 \mathrm{~m}$, which translates to \pm 0.386 - $\mathrm{m}$ accuracy at 95 percent confidence level, and is consistent with the American Society for Photogrammetry and Remote Sensing (American Society for Photogrammetry and Remote Sensing, 2015) 20 -cm vertical RMSE class.

For the $\mathrm{L} 8 \mathrm{blue} / \mathrm{green}$ and coastal/red band ratios and the WV-3 satellite-derived bathymetry (SDB), the mean errors for depths up to $4 \mathrm{~m}$ are $-0.199 \mathrm{~m},-0.913 \mathrm{~m}$, and $1.253 \mathrm{~m}$, respectively, while the mean error for depths greater than $4 \mathrm{~m}$ (up to the optical extinction depth) are $1.004 \mathrm{~m}, 0.336 \mathrm{~m}$, and $0.810 \mathrm{~m}$, respectively (table 4). These results identify not only the bias in the data, but also show that L8-derived bathymetry has a bimodal distribution. The total area covered by SDB is approximately 3.56 percent of the total area. This is one of the first attempts to use SDB for shallow nearshore bathymetry in the context of a tropical carbonate platform.

The Majuro Atoll TBDEM is the first seamless, topobathymetric digital model for this area with a high enough vertical and horizontal accuracy to adequately analyze the impact of extreme inundation events on atoll geomorphology and fresh groundwater lenses. The TBDEM will also help to better understand the geomorphic dynamics and the processes controlling the development and changes of atoll landforms.

\section{Recommendations for Topographic Unmanned Aircraft Systems (UAS) Surveys}

Utilizing UAS for elevation data acquisitions has three main advantages including (1) relatively low equipment cost, (2) low deployment cost, and (3) short data acquisition time. But processing a large volume of data to obtain a 3D point cloud at survey grade accuracy and precision can be time consuming, and sometimes unachievable if attention to survey planning is not taken into account. Therefore, we recommend the following to eliminate errors during data acquisition:
- Depending on the quality of the optical instrument used, 75 percent forward overlap may be too much; 70 percent may be more efficient.

- Make sure targets are laid down before the UAS survey.

- Make sure that at least one target is placed in the overlap areas of adjacent flight polygons.

- Ideally, the targets should be measured with the Global Navigation Satellite System (GNSS) before or after the UAS flight mission is completed, and not during the UAS flight, to avoid capturing the tripod or people obscuring the target in the photograph.

- Do not put targets under tree or building shadows, or too close to trees, fences, or walls.

- If targets are placed in tidal areas, make sure that the targets will not be displaced by incoming tides during the UAS survey.

- When collecting nadir and oblique imagery during the same mission, ensure the targets are placed far enough toward the shore edge to be visible from both modes of camera orientation.

- In coastal areas, it is better to do the survey at low tide.

- Take multiple photographs and good field notes of visually identifiable points (VIP) if they are surveyed with GNSS.

- Ideally, the camera lens calibration (for PhotoScan) should be performed onsite in the same conditions as the field work.

- When processing the data, before initial camera alignment, delete all photographs at takeoff up to the cruise altitude, and at landing.

- Joint Photographic Experts Group (.jpg) format photographs introduce distortions; use raw format photographs, if possible.

- The DJI Phantom 4 optical instrument uses a rolling shutter; using cameras with a global shutter is preferable.

- Keep good field notes for the entire survey, including records about weather, environmental conditions, and time for each flight mission and area. 


\section{Acknowledgments}

The work presented in this report on the Majuro Atoll topobathymetric digital elevation model (TBDEM) was a collaboration between the U.S. Geological Survey (USGS) and a number of cooperators. Contributions and responsibilities of the report's authors and cooperator team members are described below.

Imagery and GNSS data were collected in Majuro in September 2016 by Jeffrey Danielson, Dean Gesch, Monica Palaseanu-Lovejoy, and Cindy Thatcher of the USGS; Maria Kottermair and Andrea Jalandoni of the University of Guam; Matthew Barbee of the University of Hawaii; Edward Carlson of the National Oceanic and Atmospheric Administration (NOAA) National Geodetic Survey (NGS); Bill Labija of the Republic of the Marshall Islands Land and Survey Office; and the local survey crew. A local geoid was created by Edward Carlson and Ross Winans of The Baldwin Group for Majuro Atoll. Global Navigation Satellite System (GNSS) data were processed by Jeffrey Danielson, Dean Gesch, and Edward Carlson. Monica Palaseanu-Lovejoy generated terrestrial topography using structure-from-motion algorithms applied to imagery collected in the field. Ground-truth and validation data for the modeled elevations were collected by the field team using survey-grade GNSS. Sandra Poppenga generated satellitederived bathymetry using the ratio of natural logarithms applied to Landsat 8 and WorldView-3 satellite imagery. The integrated TBDEM was assimilated by Dean Tyler and Jeffrey Danielson. Edward Carlson and Bill Labija provided leadership in facilitating and orchestrating field work.

We thank Mark Stege of the Marshall Islands Conservation Society; Karl Fellenius (Coastal Resource Advisor) for the Republic of the Marshall Islands Environmental Protection Authority; and Norman Splittstoesser (Directorate of Civil Aviation) for assisting with the logistics. We thank the Naval Oceanographic Office for their Compact Hydrographic Airborne Rapid Total Survey (CHARTS) bathymetric lidar data that were used to calibrate the modeled bathymetry. We thank the Pacific Islands Ocean Observing System for their Pacific Islands Applied Geoscience Commission bathymetry source data along with a special thanks to Tony Kimmet of the United States Department of Agriculture for providing the DigitalGlobe WorldView-3 satellite imagery. We also thank Clinton Behrns, the National Geospatial-Intelligence Agency, and the Maritime Safety Office for the Republic of the Marshall Islands Majuro Atoll chart soundings. In-kind support was provided by the Republic of the Marshall Islands personnel who went above and beyond their daily jobs to help this work succeed.
Funding for this project was provided by the Department of Interior Pacific Islands Climate Science Center, the U.S. Geological Survey Coastal and Marine Geology Program, and the National Oceanic and Atmospheric Administration.

\section{References Cited}

American Society for Photogrammetry and Remote Sensing, 2015, Positional accuracy standards for digital geospatial data: Photogrammetric Engineering \& Remote Sensing, v. 81, no. 3, p. A1-A26. [Also available at https://doi.org/10.14358/PERS.81.3.A1-A26.]

Danielson, J.J., Poppenga, S.K., Brock, J.C., Evans, G.A., Tyler, D.J., Gesch, D.B., Thatcher, C.A., and Barras, J.A., 2016, Topobathymetric elevation model development using a new methodology - Coastal National Elevation Database: Journal of Coastal Research, Special Issue 76, p. 75-89, accessed October 10, 2017, at https://doi.org/10.2112/SI76-008.

DigitalGlobe, 2016, WorldView-3 data sheet: DigitalGlobe, 2 p., accessed October 10, 2017, at http://content.satimagingcorp. com.s3.amazonaws.com/static/satellite-sensor-specification/ WorldView-3-PDF-Download.pdf.

Furukawa, Yasutaka, Curless, Brian, Seitz, S.M., and Szeliski, Richard, 2010, Towards Internet-scale multi-view stereo [poster], in [Proceedings] 2010 IEEE Conference on Computer Vision and Pattern Recognition (CVPR 2010), San Francisco, Calif., June 13-18, 2010: Piscataway, N.J., Institute of Electrical and Electronics Engineers, p. 1,434 1,441. [Also available at https://doi.org/10.1109/ CVPR.2010.5539802.]

Furukawa, Yasutaka, and Ponce, Jean, 2007, Accurate, dense, and robust multi-view stereopsis, in 2007 IEEE Conference on Computer Vision and Pattern Recognition, Minneapolis, Minn., June 17-22, 2007, Proceedings: Piscataway, N.J., Institute of Electrical and Electronics Engineers (IEEE), p. 1-8. [Also available at https://doi.org/10.1109/CVPR.2007.383246.]

Heidemann, Hans Karl, 2014, Lidar base specification (ver. 1.2, November 2014): U.S. Geological Survey Techniques and Methods, book 11, chap. B4, 67 p. with appendixes, accessed October 10, 2017, at https://doi.org/10.3133/tm11B4.

Helweg, David, Nash, Sarah, and Polhemus, Dan, 2014, The Pacific Islands Climate Science Center five-year science agenda, 2014-2018: U.S. Geological Survey Open-File Report 2014-1075, 30 p., accessed October 10, 2017, at https://doi.org/10.3133/ofr20141075. 
International Hydrographic Organization, 2008, IHO standards for hydrographic surveys (5th ed.): Special Publication No. 44, Monaco, International Hydrographic Bureau, 28 p. [Also available at https://www.iho.int/iho_pubs/standard/S44_5E.pdf.]

International Hydrographic Organization, Intergovernmental Oceanographic Commission, 2015, The IHO-IOC GEBCO cook book: IHO Publication B-11, Monaco, International Hydrographic Organization, 429 p., accessed October 10, 2017, at http://www.gebco.net/data_and_products/gebco_ cook_book/.

Kruger, J., and Kumar, S., 2008, High-resolution bathymetric survey of Majuro, Republic of Marshall Islands: EU EDF 9-SOPAC Project Report 117, Suva, Fiji, Pacific Islands Applied Geoscience Commission, 39 p. and 2 charts.

Lague, Dimitri, Brodu, Nicolas, and Leroux, Jérôme., 2013, Accurate 3D comparison of complex topography with terrestrial laser scanner-Application to the Rangitikei canyon (N-Z): ISPRS Journal of Photogrammetry and Remote Sensing, v. 82 , p. 10-26.

Maune, D.F., Maitra, J.B., and McKay, E.J., 2007, Accuracy standards \& guidelines, in Maune, D.F., ed., Digital elevation model technologies and applications-The DEM users manual ( $2 \mathrm{~d}$ ed.): Bethesda, Md., American Society for Photogrammetry and Remote Sensing, p. 65-97.

National Geospatial-Intelligence Agency, Maritime Safety Office, 2017, North Pacific Ocean Republic of the Marshall Islands Majuro Atoll digital nautical chart 12 vector product format [chart DNCDX012 - Japan/North Pacific]: U.S. Navy surveys of 1944 and 2006, National Geospatial-Intelligence Agency Maritime Operation web page, accessed December 13, 2017, at https://nnc.nga.mil/DNC/Chart01.php?chart=12.

Naval Oceanographic Office, 2006a, Report of survey, Republic of the Marshall Islands (RMI): archive number 06H3A03, survey dates April 22 to May 1, 2006, 33 p. [Data available upon request to Naval Oceanographic Office (NAVOCEANO).]

Naval Oceanographic Office, 2006b, Data processing report, Republic of the Marshall Islands (RMI): archive number 06H3A03, survey dates April 22 to May 1, 2006, 18 p. [Data available upon request to Naval Oceanographic Office (NAVOCEANO).]

Palaseanu-Lovejoy, Monica, Danielson, J.J., Gesch, D.B., Kottermair, Maria, Jalandoni, Andrea, Barbee, Matt, Carlson, Edward, and Thatcher, C.A., 2017b, Improving elevation mapping in the Pacific; Majuro Atoll, RMI-1-meter DEM Project: U.S. Geological Survey, poster presented at Federal Unmanned Aircraft Systems (UAS) Workshop, NASA Ames Research Center, Mountain View, Calif., March 28-30, 2017. [Also available at https://topotools.cr.usgs.gov/posters/UAS Ames_2017_majuro_team1.jpg.]
Palaseanu-Lovejoy, Monica, Poppenga, S.K., Danielson, J.J., Tyler, D.J., Gesch, D.B., Kottermair, Maria, Jalandoni, Andrea, Carlson, Edward, Thatcher, Cindy, and Barbee, Matt, 2017a, One-meter topobathymetric digital elevation model for Majuro Atoll, Republic of the Marshall Islands, 1944 to 2016: U.S. Geological Survey data release, https://doi.org/10.5066/F7416VXX.

Pe'eri, Shachak, Madore, Brian, Alexander, Lee, Parrish, C.E., Armstrong, A.A., Azuike, Chukwuma, and Tetteh, E., 2013, LANDSAT 8 satellite-derived bathymetry, in Marks, K.M., ed., The IHO-IOC GEBCO cook book, edition 11.1.13: Monaco, International Hydrographic Office (IHO) and International Ocean Commission (IOC), p. 243-304.

Poppenga, S.K., 2017, Evaluating the potential for near-shore bathymetry on the Majuro Atoll, Republic of the Marshall Islands, using Landsat 8 and WorldView-3 imagery [abs.]: presentation at PECORA 20-Observing A Changing Earth; Science for Decisions Monitoring, Assessment, and Projection, 20th William T. Pecora Memorial Remote Sensing Symposium, Sioux Falls, S. Dak., November 13-16, 2017, Bethesda, Md., American Society for Photogrammetry and Remote Sensing.

Republic of the Marshall Islands, Economic Policy, Planning, and Statistics Office, 2012, The RMI 2011 census of population and housing-Summary and highlights only: Republic of the Marshall Islands Census Final Report, 23 p., accessed October 2, 2017, at https://www.doi.gov/sites/doi.gov/files/ migrated/oia/reports/upload/RMI-2011-Census-SummaryReport-on-Population-and-Housing.pdf.

Smith, M.W., Carrivick, J.L., and Quincey, D.J., 2016, Structure from motion photogrammetry in physical geography: Progress in Physical Geography, v. 40, no. 2, p. 247-275. [Also available at https://doi.org/10.1177/0309133315615805.]

Spalding, Mark, Ravilious, Corinna, and Green, E.P., 2001, World atlas of coral reefs: Berkeley, Calif., University of California Press, 424 p. [Also available at http://fnad.org/Documentos/worldatlasofcora01spal.pdf.]

SPC Geosciences, Secretariat of the Pacific Islands Applied Geoscience Commission (SOPAC), 2008, High-resolution bathymetric survey of Majuro, reducing vulnerability of Pacific ACP States, October 2008: Suva, Fiji, Pacific Islands Applied Geoscience Commission, Republic of Marshall Islands Technical Report EU-EDF 9 [SOPAC Project Report 117], accessed October 2, 2017, at http://ict.sopac.org/VirLib/ER0117.pdf.

Spennemann, D.H.R., 1992, Cultural resource management plan for Majuro Atoll, Republic of the Marshall Islands [2 vols.]: Washington, D.C., U.S. Department of the Interior, Office of Territorial and International Affairs, Part I [Management Plan], 543 p., Part II [Appendixes], 352 p. 
Thatcher, C.A., Brock, J.C., Danielson, J.J., Poppenga, S.K., Gesch, D.B., Palaseanu-Lovejoy, M.E., Barras, J.A., Evans, G.A., and Gibbs, A.E., 2016, Creating a Coastal National Elevation Database (CoNED) for science and conservation applications: Journal of Coastal Research, Special Issue 76, p. 64-74, accessed October 2, 2017, at https://doi.org/10.2112/SI76-007.

Trimble Navigation Limited, 2008, Trimble R8 GNSS and R6/5800 GPS receivers user guide (revision A): Dayton, Ohio, Trimble Navigation Limited, 86 p.

U.S. Army Corps of Engineers, 1989, Majuro Atoll coastal resource atlas: Honolulu, Hawaii, U.S. Army Corps of Engineers, Pacific Ocean Division, 1 sheet, scale 1:100,000, 53-p. text.

U.S. Geological Survey, 2016, Landsat 8 multispectral imagery dated 030116: U.S. Geological Survey EarthExplorer web page, accessed July 7, 2017, at https://earthexplorer.usgs.gov/.
Westoby, M.J., Brasington, J., Glasser, N.F., Hambrey, M.J., and Reynolds, J.M., 2012, 'Structure-from-motion' photogrammetry-A low-cost, effective tool for geoscience applications: Geomorphology, v. 179, p. 300-314. [Also available at https://doi.org/10.1016/j.geomorph.2012.08.021.]

Yamano, Hiroya, Kayanne, Hajime, Yamaguchi, Toru, Kuwhara, Yuji, Yokoki, Hiromune, Shimazaki, Hiroto, and Chikamori, Masashi, 2007, Atoll island vulnerability to flooding and inundation revealed by historical reconstructions-Fongafale islet, Funafuti atoll, Tuvalu: Global and Planetary Change, v. 57, nos. 3-4, p. 407-416. [Also available at https://doi.org/10.1016/j.gloplacha.2007.02.007.]

Yasukochi, Toru, Kayanne, Hajime, Yamaguchi, Toru, and Yamano, Hiroya, 2014, Sedimentary facies and Holocene depositional processes of Laura island, Majuro Atoll: Geomorphology, v. 222, p. 59-67. [Also available at https://www.sciencedirect.com/science/article/pii/ S0169555X14002207.] 
Manuscript was approved March 21, 2018

Prepared by the USGS Science Publishing Network Reston Publishing Service Center

For more information about this publication, contact: Eastern Geographic Science Center

U.S. Geological Survey

Mail Stop 521

12201 Sunrise Valley Drive

Reston, VA 20192

https://egsc.usgs.gov/ 
